\section{Journal of Anatolian Environmental and Animal Sciences (Anadolu Çevre ve Hayvancılık Bilimleri Dergisi) \\ Doi: https://doi.org/10.35229/jaes.544799}

\title{
First Isolation of Acinetobacter radioresistens from Golden grey mullet (Liza aurata) in Turkey ${ }^{[* 1}$
}

\author{
Mustafa TÜRE ${ }^{1^{*}}$ \\ Ayça ALTUNTAŞ 1 \\ İlyas KUTLU ${ }^{1}$ \\ ${ }^{1 *}$ Department of Fisheries Health, Central Fisheries Research Institute, Trabzon, Turkey. (D): https://orcid.org/0000-0001-9878-826X \\ ${ }^{1}$ Department of Fisheries Health, Central Fisheries Research Institute, Trabzon, Turkey. \\ (D): https://orcid.org/0000-0002-2916-8195 D: $\quad$ (Dttps://orcid.org/0000-0002-6096-6478
}

How to cite: Türe, M., Altuntaş, M. \& Kutlu, İ. (2019). First Isolation of Acinetobacter radioresistens from Golden grey mullet (Liza aurata) in Turkey. Anatolian Env. and Anim. Sciences, 4(2), 111-114.

Atıf yapmak için: Türe, M., Altuntaș, M. \& Kutlu, İ. (2019). Acinetobacter radioresistens' in Türkiye'de altınbaş kefallerden (Liza aurata) ilk izolasyonu Anadolu Çev. ve Hay. Dergisi, 4(2),111-114.

\begin{abstract}
In this study, the bacteriological examination was performed in golden grey mullet (Liza aurata) with suspected infection which kept in the hatchery facility of Central Fisheries Research Institute (CFRI), Turkey. During the disease outbreak, 35\% of the grey mullet $(400-420 \mathrm{~g})$ have died. The most important external clinical signs were anorexia, lethargy, dark pigmentation, and hemorrhage at the base of the pectoral and anal fins. Bacteria were isolated from head-kidney and liver. The pure bacteria was identified as Acinetobacter radioresistens by rapid test kit (API 20NE, Profile: 0400032). The antibacterial susceptibility of bacteria against five different antibiotics was determined by the disk diffusion method. The bacteria were sensitive to enrofloxacin, trimethoprim+sulfamethoxazole, oxytetracycline, whereat resistant to florfenicol and erythromycin. The most effective antibiotic was enrofloxacin. When symptoms persist, enrofloxacin was administered (10 $\mathrm{mg} / \mathrm{kg} / 2$ days, active ingredient) intraperitoneally. Fish were recovered after antibiotic treatment. In this study, an infection caused by Acinetobacter radioresistens was reported in golden grey mullet. Overall, to our knowledge, this study reports the first Acinetobacter infection in cultured golden grey mullet.
\end{abstract}

Keywords: Fish, golden grey mullet, fish diseases, Acinetobacter radioresistens.

\section{Acinetobacter radioresistens'in Türkiye'de altınbaş kefallerden (Liza aurata) ilk izolasyonu}

Öz: Bu çalışmada, Türkiye'de, Su Ürünleri Merkez Araştırma Enstitüsü (SUMAE)'ne ait kuluçkahanede yetiştirilen altınbaş kefaller (Liza aurata), hastalık şüphesi sonrası bakteriyolojik olarak araştırılmıştır. Salgın esnasında, 400-420 g arasında bulunan kefallerin \%35'i ölmüştür. En önemli klinik belirtiler, iştahsızlık, uyuşukluk, kararma ve anal ve gögüs yüzgeci kaidesinde kanamalardır. Bakteri, balıkların karaciğer ve ön-böbreklerinden izole edilmiştir. Saflaştırılan bakteriler, hızlı test kiti (API 20NE, Profile: 0400032) ile Acinetobacter radioresistens olarak isimlendirilmiştir. Bakterinin antimikrobiyal duyarlılığı beş farklı antibiyotiğe karşı disk difüzyon metodu ile belirlenmiştir. Bakteri, enrofloksasin, trimethoprim-sulfamethaksazol ve oksitetrasiklin antibiyotiklerine karşı duyarlı, florfenikol ve eritromisin antibiyotiklerine karşı ise dirençli olarak bulunmuştur. En etkili antibiyotik enrofloksasindir. Semptomlar devam ederken, balıklar periton-içi enrofloksasin uygulaması (10 mg/kg/2 gün) ile tedavi edilmişlerdir. Bu çalışmada, altınbaş kefallerde Acinetobacter radioresistens'in sebep olduğu bir enfeksiyon rapor edilmiştir. Sonuç olarak, bizim bilgimize göre, kültürü yapılan kefallerde rapor edilen ilk Acinetobacter enfeksiyonudur. 


\section{INTRODUCTION}

Bacterial fish diseases are one of the major problems in aquaculture and can lead to severe economic losses in many countries. Sustainability and success in aquaculture depend on prevention of fish diseases and effective fish health management (Toranzo et al., 2005; Kayış et al., 2017; Ture \& Kutlu, 2018; Balta \& Dengiz Balta, 2016). Acinetobacter sp. is a bacterium belonging to the family Moraxellaceae. Acinetobacter radioresistens is a bacteria which aerobic, Gram-negative, short-rod, non-motile, oxidase-negative and catalase-positive. Acinetobacteriosis are frequently encountered in nosocomial infections, in particular in infections in intensive care units (Coyne et al., 2011). It is also frequently found in the intestinal flora of fish, on gills and skin of aquatic animals. Because of this reason, bacteria can lead to diseases transmission easily (Austin \& Austin, 2007). The first Acinetobacter infection was observed in mature Atlantic salmon (Salmo salar) in Norway. Affected fish had anorexia, dark pigmentation, hemorrhage and edema at the base of the pectoral, pelvic, and anal fins (Austin \& Austin, 2007). Acinetobacter outbreak with high mortality was reported in different rainbow trout (Oncorhynchus mykiss) farms in Turkey in 2008 (Yonar et al., 2010).

Mullets (Mugilidae) are omnivorous fishes living in schools, mostly in coastal regions of tropical and subtropical seas. It is represented by about 13 genera and 70 species in world seas (McDowal, 1988). Majority of the Mugilidae species live in the Mediterranean and the Black Sea. Eight Mugilidae species live in Turkish waters: Liza aurata, Liza saliens, Chelon labrosus, Liza ramada, Oedalachilus labeo, Liza abu, Liza carinata, and Liza haematocheila. The members of the Mugilidae family are euryhaline species tolerated the salinities of $0 \%$ o- $60 \%$. Their also tolerances to temperature changes extremely high and can survive the temperatures between 3 and $30^{\circ} \mathrm{C}$ (Shapiro, 1998). Mullet production in Turkey is constantly decreasing trend in recent years; the production in 2017 (2313 tons) was approximately $1 \%$ of total fisheries production (269, 676 tons) (TSI, 2018).

In the present study, the first Acinetobacter infection in golden grey mullet (Liza aurata) was reported. Biochemical properties of the bacteria were also described

\section{MATERIAL and METHOD}

Bacterial examination: The project was approved by the Local Ethical Committee of the CFRI, (Protocol No: 2017/2). The disease outbreak occurred during the Autumn of 2018 in golden grey mullet which kept in an aquaculture facility of Central Fisheries Research Institute (CFRI), Trabzon, Turkey. During the disease outbreak, ten fish died and moribund grey mullet were sampled for bacterial examination. Size of the affected fish was ranged between
$400 \mathrm{~g}$ and $420 \mathrm{~g}$. The water temperature was $18^{\circ} \mathrm{C}$ during the infection. Liver and head-kidney of affected fish were aseptically streaked on Tryptic Soy Agar (TSA, Merck) and incubated at $22{ }^{\circ} \mathrm{C}$ for 2 days. After that, typical colonies were selected from the plate and streaked onto the same media to check the purity of bacteria. The pure colonies were biochemically characterized by following biochemical tests: Gram staining, motility, cytochrome oxidase, and catalase. Analytical Profile Index (API 20 NE test, Biomerieux) was performed to biochemically identify bacteria species (Altinok et al., 2007).

Antimicrobial Susceptibility Test: The antibacterial susceptibility of bacteria was evaluated against five different antibiotics. Antimicrobial susceptibility test was performed by the disk diffusion method using commercial discs (Oxoid) on Mueller Hinton Agar (MHA, Oxoid) plates. The test was performed according to the Clinical and Laboratory Standards Institute guidelines (CLSI, 2014). The commercial antibiotic discs used in this study are florfenicol (FFC, 30 $\mu \mathrm{g}$ ), enrofloxacin (ENR, $5 \mu \mathrm{g}$ ), oxytetracycline (OT; $30 \mu \mathrm{g}$ ), erythromycin $(\mathrm{E}, 15 \mu \mathrm{g})$ and trimethoprim-sulfamethoxazole (SXT; $25 \mu \mathrm{g}$ ). The plates were incubated at $30^{\circ} \mathrm{C}$ for $22 \mathrm{~h}$. The isolate was characterized as susceptible or resistant to the antibiotics.

\section{RESULTS}

Mass mortalities occurred in adult golden grey mullet and mortality reached $35 \%$ during the Autumn of 2018. Externally, affected fish had anorexia, lethargy, dark pigmentation and hemorrhage at the base of the pectoral, and anal fins. Surprisingly diseased fish did not have any internal abnormality. Bacteria were isolated from 8 out of 10 examined fish. Short and rod-shaped bacteria were gramnegative, nonmotile and nonoxidative while catalase test result was positive. Bacteria were characterized as Acinetobacter radioresistens by API 20 NE test (Profil: 0400032, \% ID: 96,7). Comparison of some biochemical characteristics of Acinetobacter radioresistens isolated from golden grey mullet in this study with the described by Austin \& Austin (2007) were shown in Table 1.

Based on antimicrobial susceptibility test, Acinetobacter sp. was susceptible to enrofloxacin, trimethoprim + sulfamethoxazole, oxytetracycline while resistant to florfenicol and erythromycin. The most effective antibiotic was enrofloxacin. When symptoms persist, enrofloxacin was administered $(10 \mathrm{mg} / \mathrm{kg} / 2$ days, active ingredient) intraperitoneally. Fish were recovered after antibiotic treatment. 


\section{DISCUSSION}

Bacteria belonging to the genus Acinetobacter are Gram-negative, aerobic, non-motile, catalase positive, oxidase negative and short-rods. Acinetobacter species are naturally found in soil, water, marine, and freshwater fish. These bacteria are recognized as emerging opportunistic pathogens of fish farmed in the worldwide (Doughari et al., 2011; Kozinska et al., 2014). The present study reports the first Acinetobacter radioresistens infection that causes high mortality in golden grey mullet.

Table 1. Comparison of some phenotypic characteristics of Acinetobacter sp. isolated from golden grey mullet in this study with the previously published study.

\begin{tabular}{lll}
\hline Biochemical features & A & B \\
\hline Gram stain & - & - \\
Motility & - & - \\
Pigmentation & - & - \\
Cytochrome oxidase & + & - \\
Catalase & + & + \\
Reduction of nitrates & - & - \\
$\beta$-galactosidase & - & - \\
$\mathrm{H}_{2} \mathrm{~S}$ & - & - \\
Indol production & - & - \\
Arginine dihydrolase & - & - \\
Hydrolysis gelatin & - & - \\
Urease & - & - \\
Galactose & + & $?$ \\
Maltose & + & - \\
Mannose & + & - \\
Glucose & - & - \\
Arabinose & - & - \\
Lactose & - & - \\
Assimilation capric acid & $?$ & + \\
Assimilation adipic acid & $?$ & + \\
Hydrolysis esculin & $?$ & + \\
Phentypic features of bacteria were obtained from, A: Austin \& Austin, (2007), B: In this study, ?: It \\
was not done.
\end{tabular}

In this study, the pathogenic bacteria were identified as Acinetobacter radioresistens based on phenotypic characterization. In a previous study, phenotypic features of Acinetobacter sp. were described by Austin \& Austin (2007). In contrast to the results detailed in our study, they described that Acinetobacter sp. with biochemical characteristics showed cytochrome oxidase, maltose, and mannose positive reactions. In another study, biochemical characteristics of Acinetobacter isolates tested by using API 20 NE system were similar to our results (Kozinska et al., 2014).

Acinetobacter strains are generally known as microorganisms transmitting the antibiotic resistance genes (Kozinska et al., 2014). In a previous study, antibiotic susceptibility tests revealed that Acinetobacter strains were sensitive to norfloxacin, and gentamicin. On the other hand, some of the strains were found resistant to cephalothin, oxytetracycline, sulfamethoxazole, chloramphenicol and amoxicillin (Yonar et al., 2010). The antibiotic susceptibility may vary depending on many factors including bacterial species, isolation area, and origin. However, in our study, the bacteria was found as sensitive to enrofloxacin, trimethoprim+sulfamethoxazole, oxytetracycline, and resistant to florfenicol and erythromycin. When symptoms persist, enrofloxacin administration surprisingly helped fish to recover.

Studies on bacteria associated with a disease outbreak in grey mullet from Turkey and different countries are very limited. The mortality records of wild and cultured mullet populations are rare. Mortalities generally are occurred due to environmental stress such as temperature, salinity, and pollution. A epizootics with up to $10 \%$ mortality were recorded on some grey mullet farms in Taiwan. In the mentioned investigation, Lactococcus garvieae was reported as a causative agent (Chen et al., 2002). In another study, the disease outbreaks in grey mullet were investigated. Vibrio harveyi, Vibrio fischeri, and Pseudoalteromonas were the main bacterial pathogens found in the mullet outbreaks (Lopes et al., 2014).

In the present study, the bacterial strain was identified to species level based on the biochemical method. According to the API 20NE result, bacteria were identified as Acinetobacter radioresistens. In conclusion, an infection caused by Acinetobacter radioresistens were reported in golden grey mullet. Overall, this study reports the first Acinetobacter infection in cultured golden grey mullet in Turkey.

\section{ACKNOWLEDGEMENTS}

The abstract of the manuscript has been submitted to publication in International Conference on Agriculture, Food, Veterinary and Pharmacy Sciences (ICAFOP-2019).

\section{REFERENCES}

Altinok, I., Balta, F., Capkin, E. and Kayis, S. (2007). Disease of rainbow trout caused by Pseudomonas luteola. Aquaculture, 273, 393-397.

Austin, B. \& Austin, DA. (2007). Bacterial fish pathogens, diseases of farmed and wild fish. 4th ed. Godalming, England: Springer-Praxis $252 \mathrm{p}$.

Balta, F. \& Dengiz Balta Z. (2016). Vibrio infection and treatment on the juvenile rainbow trout (Oncorhynchus mykiss) transferred seawater. Journal of Anatolian Environmental and Animal Sciences, 1(1), 14-20.

Chen, S.C., Liaw, L.L., Su, H.Y., Ko, S.C., Wu, C.Y., Chaung, H.C., Tsai, Y.H., Yang, K.L., Chen, Y.C., Chen, T.H., Lin, G.R., Cheng, S.Y., Lin, Y.D., Lee, J.L., Lai, C.C., Weng, Y.J. \& Chu, S.Y. (2002). Lactococcus garvieae, a cause of disease in grey mullet, Mugil cephalus L., in Taiwan. Journal of Fish Diseases, 25, 727-732.

CLSI. (2014). Clinical and Laboratory Standards Institute. Performance Standards for Antimicrobial Susceptibility Testing; Twenty-Fourth Informational Supplement, M100-S24. 
Coyne, S., Courvalin, P. \& Perichon, B. (2011). EffluxMediated Antibiotic Resistance in Acinetobacter spp. Antimicrobial Agents and Chemotherapy, 55, 947-953.

Doughari, HJ., Ndakidemi, PA., Human, IS. \& Benade, S. (2011). The ecology, biology and pathogenesis of Acinetobacter spp.: an overview. Microbes and Environments, 26, 101-112.

Kayış, Ş., Er, A. \& İpek, Z. (2017). Effects of albinism on Pseudomonas putida infection on convict cichlid (Cichlasoma nigrofasciatum). Journal of Anatolian Environmental and Animal Sciences, 2(3), 51-52.

Kozinska, A., Pazdzior, E., Pękala, A. \& Niemczuk, W. (2014). Acinetobacter johnsonii and Acinetobacter lwoffii the emerging fish pathogens. Bull Vet Inst Pulawy, 58, 193-199.

Lopes CR., Marin-Arjona MC., Lopez-Sanmartin, M. and Navas-Triano, J I. (2014). Bacteria associated to disease outbreaks in grey mullet (Mugil cephalus) and Brill (Scophthalmus rhombus). Conference: Aquaculture Europe 2014.

Mc Dowal, RM. (Ed). (1988). Diadromy in fishes Migration between freshwaters and marine environments. Croom Helm, London, 308p.

Shapiro, J. (1998). Food of the Thin-Lipped Grey Mullet (Liza ramada) in Lake Kinneret, The Israeli J.Aquaculture- Bamidgeh, 50, 3-11.

Tamura, K., Peterson, D., Peterson, N., Stecher, G., Nei, M. \& Kumar, S. (2011). MEGA5: Molecular evolutionary genetics analysis using maximum likelihood, evolutionary distance, and maximum parsimony methods. Molecular Biology and Evolution, 28, 2731-2739.
Toranzo, AE., Magarinos, B. and Romalde, JL. (2005). A review of the main bacterial fish diseases in mariculture systems. Aquaculture, 246, 37-61.

TSI. (2018). Turkish Statistical Institute, www.turkstat.gov.tr. Access date: 21.01.2019.

Ture, M. \& Kutlu, I. (2018). Isolation of Citrobacter freundii from Rainbow Trout (Oncorhynchus mykiss) in Freshwater Cage. Journal of Limnology and Freshwater Fisheries Research, 4, 85-89.

Yonar, ME., Karahan, M., Kan, NI., Yonar, S. \& Sağlam, N. (2010). A study of Acinetobacter sp. infection in some cultured rainbow trout (Oncorhynchus mykiss) in Kahramanmaras. Journal of Fisheries Sciences.com, 4, 287-293.

*Corresponding author's:

Mustafa TÜRE

Su Ürünleri Merkez Araştırma Enstitüsü, Vali Adil Yazar C. Yomra, Trabzon, Turkey.

\E-mail: mustafa.ture@tarimorman.gov.tr

ORCID: https://orcid.org/0000-0001-9878-826X 